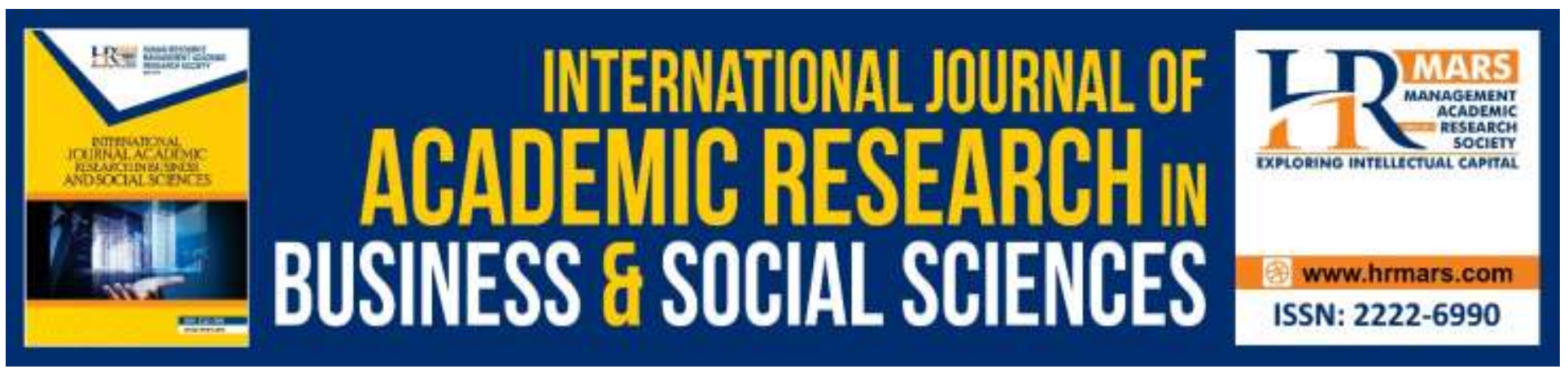

\title{
The Relationship Between Professional Learning Community with Teacher Attitudes Towards Change
}

Mohd Aizat Abu Hassan, Kamarudin Musa

To Link this Article: http://dx.doi.org/10.6007/IJARBSS/v10-i4/7109

DOI:10.6007/IJARBSS/v10-i4/7109

Received: 09 February 2020, Revised: 28 February 2020, Accepted: 19 March 2020

Published Online: 11 April 2020

In-Text Citation: (Hassan \& Musa, 2020)

To Cite this Article: Hassan, M. A. A., \& Musa, K. (2020). The Relationship Between Professional Learning Community with Teacher Attitudes Towards Change. International Journal of Academic Research in Business and Social Sciences, 10(4), 88-96.

Copyright: (C) 2020 The Author(s)

Published by Human Resource Management Academic Research Society (www.hrmars.com)

This article is published under the Creative Commons Attribution (CC BY 4.0) license. Anyone may reproduce, distribute, translate and create derivative works of this article (for both commercial and non-commercial purposes), subject to full attribution to the original publication and authors. The full terms of this license may be seen at: http://creativecommons.org/licences/by/4.0/legalcode

Vol. 10, No. 4, 2020, Pg. $88-96$

http://hrmars.com/index.php/pages/detail/IJARBSS

JOURNAL HOMEPAGE

Full Terms \& Conditions of access and use can be found at http://hrmars.com/index.php/pages/detail/publication-ethics 


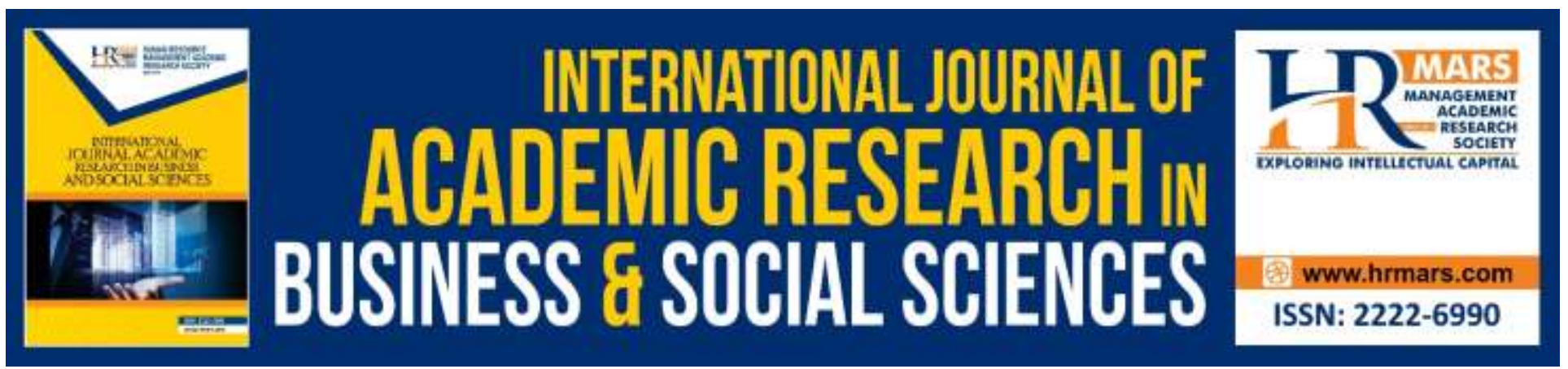

\title{
The Relationship Between Professional Learning Community with Teacher Attitudes Towards Change
}

\author{
Mohd Aizat Abu Hassan \\ Faculty of Management and Economics, Universiti Pendidikan Sultan Idris, Tanjung Malim, Malaysia \\ Email: q000624@siswa.upsi.edu.my \\ Kamarudin Musa* \\ Faculty of Management and Economics, Universiti Pendidikan Sultan Idris, Tanjung Malim, Malaysia \\ Email: kamarudin@fpe.upsi.edu.my \\ * Corresponding author.
}

\begin{abstract}
Teachers are a vital factor contributing to the changes currently underway and through the Professional Learning Community as proposed in the Malaysian Education Development Plan 20132025. There are two parts to this research instrument; the first is the Professional Learning Community instrument, which consists of three sections, namely the critical elements, human resources, and structure of the school. In contrast, the second instrument is the Instrument of Teacher Attitude Towards Change that includes three dimensions, namely cognitive, affective, and behavioural. The findings show that there is a very weak negative relationship and insignificant between the two variables.
\end{abstract}

Keywords: Professional Learning Community, Teacher Attitude Towards Change, Malaysian Education Development Plan.

\section{Introduction}

Various efforts are being undertaken by the Ministry of Education Malaysia (MOE) in tandem with the rapidly changing knowledge and information sector aimed at improving the quality of education in Malaysia. These changes require that everyone in the education sector make the paradigm shift, especially for teachers, by enhancing their professional knowledge and skills. Therefore, to produce students with knowledge and skills, some things need to be addressed by all parties. Individuals need to develop their skills, especially teachers involved in making changes. The Professional Learning Community (PLC) has long been used in developed countries to enhance pedagogy among their educators. Consistent implementation must implement so that the PLC can have maximum impact on the PLC culture. It because the PLC can develop a high perception of learning among teachers 
INTERNATIONAL JOURNAL OF ACADEMIC RESEARCH IN BUSINESS AND SOCIAL SCIENCES Vol. 10, No. 4, April, 2020, E-ISSN: 2222-6990 C 2020 HRMARS

through the inclusion of a learning culture among every member of the school community (Hord, 1997; Zuraidah, 2010).

The Malaysian Education Development Plan 2013 - 2025 (MEDP) proposes the PLC as a means of enhancing teacher professionalism through knowledge sharing among teachers and school staff. Culturing PLC in schools is an ongoing effort that helps teachers improve their pedagogy so that teaching can be useful and sustainable. The PLC connects schools with school-based professionals to continue to share learning to improve student achievement by applying the knowledge they have learned. However, the learning community involves interpersonal relationships such as warmth shown in families, neighbours, or any group that is carefully related and tends to families with pure intentions (Senge, 1990; Hord, 1997).

\section{Problem Statement}

The Malaysian Education Development Plan (MEDP) 2013-2025 in the process of transforming education that involves large-scale changes requires teachers to be agents of change. Therefore, the Ministry of Education Malaysia (MOE) has proposed the Professional Learning Community (PLC) as a way to help teachers get involved in this change. Teachers are one of the main factors that are driving the change that is happening now. Still, if this is the attitude of the teacher towards the move, it will slow down and slow down the transition. Although teachers are in an ever-changing dynamic environment, teachers' attitudes toward change (TATC) remain a question mark. According to the Tai study in 2017, many teachers do not have high TATC. However, fewer studies have been conducted to determine the relationship between PLC and TATC in Malaysia.

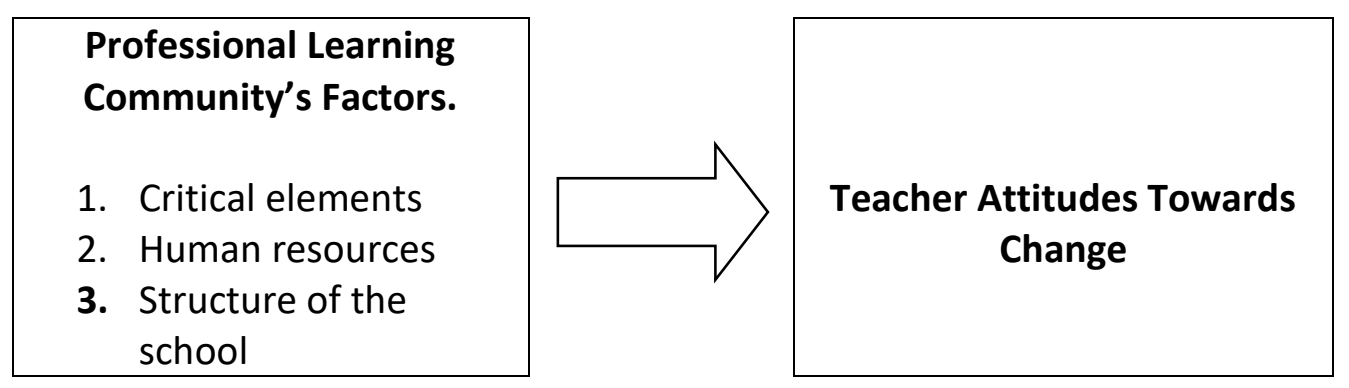

Figure 1: Conceptual Framework

\section{Literature Review}

\section{Professional Learning Community}

Professional Learning Community (PLC) is a culture of learning in the school where teachers are learning, and students also learn all the communities in the school are learning together. Some academics define the PLC as one who continues to learn to adapt to the ever-changing changes. Teachers in schools who practice PLC can help change their teaching practices and focus on the learning and teaching needs of active students. In other words, the PLC concern with developing a new culture in schools that are learning culture and continuing to learn as it evolves. The PLC today is the most powerful strategy and structure in efforts to improve and improve school effectiveness (Carla, 2009; Scherer, 2009; Zuraidah, Rahimah, Muhammad, \& Hailan, 2012). 
INTERNATIONAL JOURNAL OF ACADEMIC RESEARCH IN BUSINESS AND SOCIAL SCIENCES Vol. 10, No. 4, April, 2020, E-ISSN: 2222-6990 @ 2020 HRMARS

Table 2: Professional Learning Community's Factors.

\begin{tabular}{|c|c|c|c|}
\hline No. & Factor & Description & Source \\
\hline 1. & $\begin{array}{l}\text { Critical } \\
\text { elements }\end{array}$ & $\begin{array}{l}\text { There are four main elements of the sharing session: (1) } \\
\text { The knowledge sharing process: the process of knowledge } \\
\text { creation and dissemination. (2) Information technology } \\
\text { infrastructure: tools and systems that support the } \\
\text { dissemination of information. (3) The catalyst: media that } \\
\text { facilitates and disseminates information. (4) Values, } \\
\text { standards, and procedures: social and cultural values that } \\
\text { influence individual thinking. }\end{array}$ & $\begin{array}{l}\text { Eriksson\& } \\
\text { Dickson } \\
(2000)\end{array}$ \\
\hline 2. & $\begin{array}{l}\text { Human } \\
\text { resources }\end{array}$ & $\begin{array}{l}\text { Human and social resources are essential for the } \\
\text { development of the PLC to include openness to } \\
\text { improvement, trust and respect, cognitive and skills } \\
\text { building, supportive leadership, and outreach, which will } \\
\text { consider in the form of mutual trust. }\end{array}$ & $\begin{array}{l}\text { (Louis \& } \\
\text { Kruse, 1995). }\end{array}$ \\
\hline 3. & $\begin{array}{l}\text { Structure of } \\
\text { the school }\end{array}$ & $\begin{array}{l}\text { Structural conditions are where, where, and how staff } \\
\text { regularly gather as units for learning, decision-making, } \\
\text { problem-solving, and creative work that characterize the } \\
\text { professional learning community. }\end{array}$ & Hord (2004) \\
\hline
\end{tabular}

\section{Teacher Attitudes Toward Change}

Teacher attitudes to change (TATC) are internal factors that influence teachers 'choices about teachers' personal preferences or the tendency to respond to change. It refers to the positive or negative overall evaluative judgment of the change initiative implemented by his school (Tai, 2013). Generally, teachers' attitudes toward change include teacher cognition about change, affective responses to change, and behavioural tendencies toward change and there are local studies showing that TATC is at a moderate level (Abu Hassan, Rabbani, Shukor \& Abdul Majid, 2018). Azwar (2010) outlined the factors that influence teachers' attitudes. First, teachers experience the effect left by personal experience, which is the basis for the formation of the attitude. The attitude becomes more comfortable when the teacher's expertise involves emotional factors. Second is the influence of essential individuals on the teacher. Individuals tend to have the same attitude as individuals who are crucial to them. The third is a cultural influence because the culture has a significant impact on the individual without realizing it. Culture shapes the experiences of its people. Fourth, through the medium of information and news should be conveyed with facts and influenced by the attitude of the speaker and change the attitude of the listener or reader. Fifth is that education, religion, and concepts conveyed through culture and religion influence the belief system. It indirectly affects the teacher's attitude and, ultimately, the emotional factor. The attitude is sometimes influenced by the emotion that serves as a channel for communicating dissatisfaction or a mechanism for defending the individual's ego.

\section{PLCs Help Change Schools}


The success of the change in school is the result of the change required by the school staff, especially the teachers. The level of readiness at the school level is a critical aspect of achieving the objectives of the implementation of the PLC. The focus on change readiness and acceptance of the PLC should focus at the school level as fundamentally improving the need for collective behaviour change in redefining school change. School readiness define as the degree of commitment to change and the effectiveness of variation shown by each layer of schoolchildren to implement change management programs within the organization, namely school (Weiner, 2009). Experienced change management specialists are essential for establishing a school readiness for change that involves a collective effort that lies within the scope of a leadership perspective.

In conclusion, elements of administrative leadership have identified as key change agents and contributing factors to the successful implementation of PLCs in schools (Kotter \& Schlesinger, 2008; Weiner, 2009; Norshidah, 2011). The outdated headteacher's leadership style is out of the 21st century and has to transform into a more strategic, innovative, and futuristic leadership style. As such, leadership elements, and strategic leadership, in particular, have been widely described as one of the critical drivers for ensuring the PLC runs effectively (Ronquillo 2011). Strategic leaders play an essential role in every strategic change implementation in the school (Lahtero \& Kuusilehto-Awale, 2013), while each of the strategic leadership actions positively contributes to effective strategy implementation (Hitt, Ireland \& Hoskisson, 2007). However, theoretically, strategic leadership is not a new category of leadership but rather a critical dimension of leadership activity (Davies \& Davies, 2006) that positively influences school performance, innovation, learning, and change (Vera \& Crossan, 2004). To increase the likelihood of success in change efforts, the focus should be on the leadership ability to lead the implementation of strategies and address any changes that may occur (Judge, Thoresen, Pucik \& Welbourne, 1999) by enhancing the element of readiness in turn (Chuzairy \& Mohammad, 2013).

\section{Methodology \\ Research Method}

A quantitative design was chosen for this study because according to Creswell's (2014) quantitative method it is appropriate to explain the relationship between variables in the research and how variables influence other variables and to determine whether these factors expected to be generated (Gay, Mills \& Airs, 2012). Also, quantitative research has been found suitable for this study that examines the effects of variables on outcomes and to test and explain theories that can apply to large populations (Creswell, 2009). This study involved teachers in Malaysian schools.

\section{Instrument of Study}

There are two parts to this research instrument. The first is a Professional student Community instrument based on the article "Building professional community in schools" by Kruse, Louis, and Bryk (1994), which contains three sections that are critical elements, human resources, and structural conditions in schools. The "School Reform Initiative" compiled the questionnaire. The second part is the adaptation of the previous study, namely Tai \& Omar's (2014) study of teacher attitude toward change, which encompasses three dimensions: cognitive, affective, and behavioural. 
INTERNATIONAL JOURNAL OF ACADEMIC RESEARCH IN BUSINESS AND SOCIAL SCIENCES

Vol. 10, No. 4, April, 2020, E-ISSN: 2222-6990 @ 2020 HRMARS

\section{Study Respondents}

A total of 384 teachers in Malaysian randomly selected as respondents for this study. The size respondents in study were determined based on the population proportions of the Krejice \& Morgan studies. The sample size based on Krejcie \& Morgan, which determines the sample size if the population size is 75,000 to $1,000,000$, requiring respondents between 382 and 384 and above (Krejcie \& Morgan, 1970).

\section{Study Findings}

The findings of this study were to find correlations between Professional Learning Community and Teacher Attitudes Towards Change.

Table 2: Correlation value and description

\begin{tabular}{cc}
\hline Correlation Values & Description \\
\hline $0.01- \pm 0.20$ & very weak \\
$\pm 0.21- \pm 0.40$ & weak \\
$\pm 0.41- \pm 0.60$ & moderate \\
$\pm 0.61- \pm 0.80$ & strong \\
$\pm 0.81- \pm 1.00$ & very strong \\
\hline
\end{tabular}

To determine the correlation values are very weak, weak, moderate, strong and very strong as suggested by Alias (1992) based on the following table 2.

Table 3: Correlation between Professional Learning

Community with Teacher Attitudes Towards Change

\begin{tabular}{lll}
\hline & \multicolumn{2}{l}{ Teacher Attitudes Towards Change } \\
\hline Professional & ${ }_{r}$ & Sig. \\
Learning & -0.053 & 0.303 \\
Community & & \\
\hline *Pearson Correlation &
\end{tabular}

Table 3 shows the Pearson correlation, $r$, is -0.053 , a very weak negative relationship, and this value is not significant $(p>0.05$ ). This $r$ value shows an indication of a very weak negative relationship and insignificant between the Professional Learning Communities and Teacher Attitudes Towards Change, $r=-0.053, n=384, p>0.05$.

Table 4: Correlation between Professional Learning Community (critical elements) with Teacher Attitudes Towards Change

\begin{tabular}{lll}
\hline & \multicolumn{2}{l}{ Teacher Attitudes Towards Change } \\
\hline Professional Learning & ${ }^{*} r$ & Sig. \\
Community & -0.098 & 0.055 \\
(critical elements) & & \\
\hline *Pearson Correlation & &
\end{tabular}


INTERNATIONAL JOURNAL OF ACADEMIC RESEARCH IN BUSINESS AND SOCIAL SCIENCES Vol. 10, No. 4, April, 2020, E-ISSN: 2222-6990 @ 2020 HRMARS

Table 4 shows the Pearson correlation, $r$, is -0.098 , a very weak negative relationship, and this value is not significant $(p>0.05)$. This $r$ value shows an indication of a very weak negative relationship and insignificant between the Professional Learning Communities (critical elements) and Teacher Attitudes Towards Change, $r=-0.098, n=384, p>0.05$.

Table 5: Correlation between Professional Learning Community (human resources) with Teacher Attitudes Towards Change

\begin{tabular}{lll}
\hline & \multicolumn{2}{l}{ Teacher Attitudes Towards Change } \\
\hline Professional & ${ } r$ & Sig. \\
Learning & -0.002 & 0.962 \\
Community & & \\
(critical elements) & & \\
\hline
\end{tabular}

*Pearson Correlation

Table 5 shows the Pearson correlation, $r$, is -0.002 , a very weak negative relationship, and this value is not significant $(p>0.05)$. This $r$ value shows an indication of a very weak negative relationship and insignificant between the Professional Learning Communities (human resources) and Teacher Attitudes Towards Change, $r=-0.002, n=384, p>0.05$.

Table 6: Correlation between Professional Learning Community (human resources) with Teacher Attitudes Towards Change

\begin{tabular}{lll} 
& \multicolumn{2}{c}{ Towards Change } \\
\hline & Teacher Attitudes Towards Change \\
\hline Professional & ${ }^{r}$ & Sig. \\
Learning & -0.040 & 0.434 \\
Community & & \\
(critical elements) & & \\
\hline
\end{tabular}

*Pearson Correlation

Table 6 shows the Pearson correlation, $r$, is -0.040 , a very weak negative relationship, and this value is not significant $(p>0.05$ ). This $r$ value shows an indication of a very weak negative relationship and insignificant between the Professional Learning Communities (human resources) and Teacher Attitudes Towards Change, $r=-0.040, n=384, p>0.05$.

\section{Conclusion}

The findings show a fragile relationship between the three PLC factors, namely critical elements, human resources, and structural conditions in schools with teachers' attitudes toward change (TATC). Therefore, changes need to be made at the school level to meet all three PLC factors to have a more positive impact on teachers' attitudes towards change (TATC). This is because TATC can be enhanced with the training, understanding, and importance of change understood by school teachers. Therefore, the importance of change should be started regularly to ensure TATC can be improved. Teachers are agents of change that are one of the critical factors for change and transformation in 
INTERNATIONAL JOURNAL OF ACADEMIC RESEARCH IN BUSINESS AND SOCIAL SCIENCES Vol. 10, No. 4, April, 2020, E-ISSN: 2222-6990 @ 2020 HRMARS

education to work smoothly and successfully. This finding can help relevant parties find solutions to ensure that PLCs can help TATC be enhanced to a high level. The researcher proposes further studies to determine the actual level of PLC implementation in schools and the actual level of teachers' understanding of PLC implementation.

\section{References}

Abu Hassan, M. A., Rabbani, M. F., Shukor, M. E., \& Majid, A. M. M. (2018). Sikap Guru Terhadap Perubahan dalam Sekolah di Malaysia. Management Research Journal, 7, 188 - 196.

Alias, B. (1997). Statistik Penyelidikan dalam Pendidikan dan Sains Sosial, Bangi: Universiti Kebangsaan Malaysia

Azwar, S. (2010). Sikap Manusia Teori dan Pengukurannya. Yogyakarta: Pustaka Pelajar.

Carla. (2009). Case study: Teacher perceptions of professional learning Communities in an elementary school setting. Ed. D. dissertation, Walden University, United States-Minnesota

Chuzairy, H., \& Mohammad, Y. A. (2013). Ke Arah Pendidikan yang Lebih Berkualiti: Pengamalan Pengajaran Guru Kimia dalam Menggalakkan Kreativiti. Prosiding 2nd International Seminar on Quality and Affordable Education.

Creswell, J. W., \& Creswell, J. D. (2014). Research Design: Qualitative, Quantitative, and Mixed Methods Approaches. Thousand Oaks, CA: SAGE Publications.

Davies, B., \& Davies, B.J. (2009).Strategic leadership. in B. Davies (2nd ed.), The Essentials of School Leadership. London: Paul Chapman.

Eriksson, I. V., \& Dickson, G. W. (2000). Knowledge sharing in high technology companies. AMCIS 2000 Proceedings. Paper 217.

Gay, L., Mills, G., \& Airasian, P. (2012). Educational Research: Competencies for Analysis and Applications. 10th Edition. NY, NY: Pearson.

Hitt, M. A., Ireland, R. D., \& Hoskisson, R. E. (2007). Strategic Management: Competitiveness and Globalization (7th Ed). Cincinnati: South-Western / Thomson Learning.

Hord, S. M. (1997). Professional Learning Unities : Co Communities of Continuous Inquiry. Leadership 40 (1): 3-55.

Judge, T., Thoresen, C., Pucik, V., \& Welbourne, T. (1999). Managerial Coping with Organizational Change: A Dispositional Perspective. Journal of Applied Psychology, 84(1),107-122.

Kotter, J. P., \& Schlesinger, L. A. (2008). Choosing Strategies for Change, Harvard Business Review

Krejcie, R. V., \& Morgan., D. W. (1970). Determining Sample Size for Research Activities. Educational and Psychological Measurement. https://doi.org/10.1177/001316447003000308.

Kruse, S., Louis, K. S., \& Bryk, A. (1994). Building Professional Community in Schools. Restructuring Schools, Issue Report No. 6 (Spring 1994): 3-6.

Lahtero, T. J., \& Kuusilehto-Awale, L. (2013). Realisation of strategic leadership in leadership teams' work as experienced by the leadership team members of basic education schools. School Leadership \& Management: Formerly School Organisation, 33(5), 457-472.

Louis, K. S., \& Kruse, S. D. (1995). Professionalism and community: Perspectives on reforming urban schools. Thousand Oaks, CA: Corwin Press.

Norshidah, N. (2011). The Influence Of Emotional Intelligence, Leadership Behaviour and Organizational Commitment On Organizational Readiness for Change in Higher Learning Institution. Procedia - Social and Behavioral Sciences, 29. 129-138. 
INTERNATIONAL JOURNAL OF ACADEMIC RESEARCH IN BUSINESS AND SOCIAL SCIENCES

Vol. 10, No. 4, April, 2020, E-ISSN: 2222-6990 @ 2020 HRMARS

Ronquillo, J. C. (2011). Servant, Transformational and Transactional Leadership. in K. A. Agard (Ed.), Leadership in nonprofit organizations: A reference handbook (345-353). Thousand Oaks, CA: Sage.

Scherer, M. (2009). Engaging the Whole Child: Reflections on Best Practices in Learning - Teaching and Leadership. Alexandria: ASCD.

Senge, P. M. (1990) The Leader's New Work: Building Learning Organizations. Harvard Business School.

Tai, M. K., \& Omar, A. K. (2014). Teachers' Attitudes Toward Change: A Study in Malaysian High Performing Secondary School. Journal of Scientific Research, 21 (3), 543-549.

Vera, D., \& Crossan, M. (2004). Strategic leadership and organizational learning. The Academy of Management Review, 29(2), $222-240$.

Weiner, B. J. (2009). A theory of organizational readiness for change. Implementation Science, $4(1), 67$.

Zuraidah, A. (2010). Pembentukan Profil Komuniti Pembelajaran Profesional Sekolah Menengah Di Malaysia. Tesis Ph.D. Institut Pengajian Kepengetuaan, Universiti Malaya. (Unpublished thesis).

Zuraidah, A., Rahimah A., Muhammad, F. A. G., \& Hailan, S. (2012). Komuniti Pembelajaran Profesional dalam Kalangan Warga Sekolah Menengah Di Malaysia. Seminar Kebangsaan Majlis Dekan Pendidikan IPTA 2012. 